\title{
The NBU's Balance Sheet: Before, During, and After the Crisis
}

\section{Iryna Kachur ${ }^{1}$}

National Bank of Ukraine

\section{Volodymyr Lepushynskyi}

National Bank of Ukraine

\section{Robert Zammit ${ }^{1,2}$}

Bank of England (on secondment to the National Bank of Ukraine)

\section{ABSTRACT}

Looking at the evolution of the central bank's balance sheet gives us a unique window on the forces that have shaped our economy and central bank reaction functions. This paper considers the evolution of the NBU's balance sheet over the period from 2001-2016, focusing on explicit and implicit monetary policy priorities at different periods. We then make simulations on the NBU's balance sheet for the next five years assuming current NBU priorities for monetary policy. We then draw conclusions on the likely financial position of the NBU in the future and recommendations to ensure the NBU's financial strength-essential for its continued independence.

JEL Codes: E58, E61, G01

Keywords: central bank finances, National Bank of Ukraine, balance sheet, central bank independence, monetary policy.

\section{INTRODUCTION}

The global economic crisis in 2008 led to a significant expansion in central bank balance sheets around the world, consistent with policy efforts to stabilize financial systems and restore economic growth. During the period of 2014 and 2015 , the National Bank of Ukraine's (NBU) balance sheet expended further in response to the combined effects of a balance of payments, fiscal and banking crisis brought on by a collapse in confidence in the economy, political turbulence, and military aggression.

As a percentage of Gross Domestic Product (GDP), the balance sheets of the NBU and that of other central banks in both developed and emerging market economies are a multiple of what they were only a decade ago (Figure 1).

\section{Figure 1. Central bank balance sheets as a percentage of annual nominal GDP}
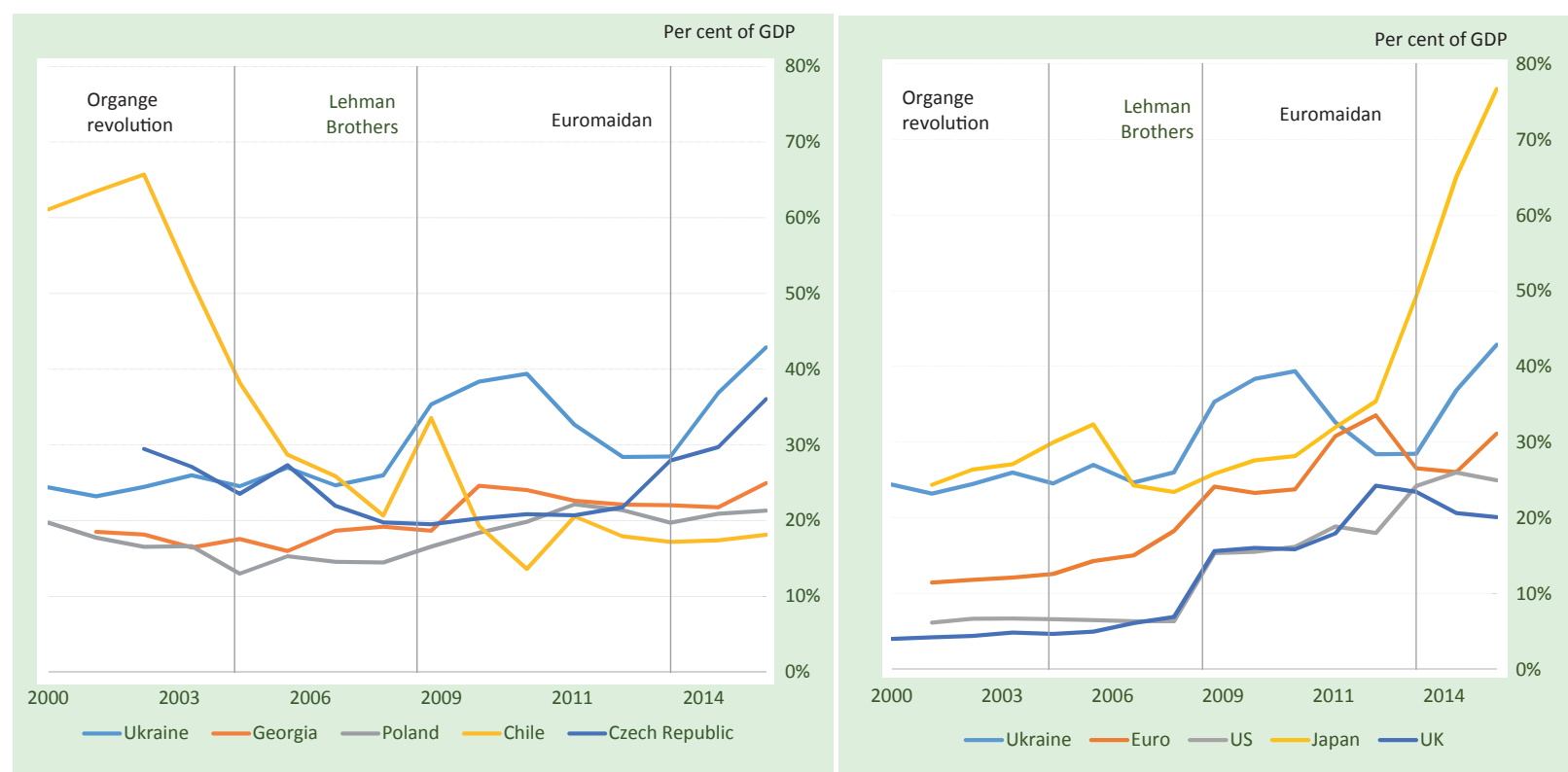

Source: NBU calculations.

\footnotetext{
${ }^{1}$ The views expressed in this paper are those of the authors and do not necessarily represent the position of the National Bank of Ukraine or the Bank of England.

${ }^{2}$ With thanks to Artur Bryzghalov and Oleksii Nahurskyi for research assistance.
} 
Central bank balance sheets serve a very different purpose to commercial bank balance sheets. Whereas in the commercial sector balance sheets serve the purely commercial function of channeling funds from savers to borrowers, central bank balance sheets serve an important policy function through the provision of central bank money to the economy.

Looking at the evolution of central banks' balance sheets gives us a unique window on the forces that have shaped our economy and central bank reaction functions. Equally, thinking about what might impact a central bank's balance sheet in the future helps us understand what policy options are available for central banks to fulfill their core functions of price and financial stability and sustainable economic growth.

This article does the following. The next section uses a simplified model to explain the main components of a central bank balance sheet. The following section explains the evolution of the NBU's balance sheet over the period of 2001-2016. We then present a simple simulation that maps the possible future evolution of the NBU's balance sheet over the period of 2016-2020, and conclude with a number of policy recommendations.

\section{A SIMPLIFIED CENTRAL BANK BALANCE SHEET: BRIEF LITERATURE REVIEW}

As noted in Archer and Moser-Boehm (2013), while the overall central bank balance sheet configuration is not something that monetary policy makers decide upon on a day-by-day basis, it is, in the end, a policy decision which balance sheet items the central bank is willing to adjust endogenously and which items it wants to steer actively in the conduct of monetary policy. Our analysis of central bank balance sheets focuses not just on the absolute and relative size of the balance sheet, but also the composition of the items within it.

We start off with a simple model of a central bank accounting balance sheet shown in Table 1 below.

\section{Table 1. Simplified central bank balance sheet}

\begin{tabular}{|c|c|}
\hline Assets & Liabilities and equity \\
\hline Foreign assets & Currency in circulation \\
Domestic assets & Commercial bank reserves \\
& Securities issued by the central bank \\
\end{tabular}

In addition to a central bank's equity or capital, the liabilities side of a central bank reflects the two sources of demand for central bank money: the demand for physical banknotes and the demand for commercial bank balances at the central bank. The asset side of the balance sheet reflects the assets that a central bank purchases - through regular open market operations or outright asset purchases - to back its liabilities.

\section{Liabilities}

Just like on any other balance sheet, the liabilities of a central bank are claims payable to others that arise from central bank operations.

Banknotes are one of the biggest components of the liability side of a central bank's balance sheet. They are provided by the central bank at the request of commercial banks, which provide them in turn to customers on demand.

The other large central bank liability is the reserve accounts of commercial banks held at the central bank. Reserve accounts are high-quality assets of commercial banks held at the central bank, and the amount held in individual accounts will fluctuate depending on payments from one commercial bank to another effected through the central bank. In some countries, central banks may set, for each bank, a specific amount to be held in each bank's reserve account, whereas, in other countries, commercial banks set the amount they wish to hold in their reserve account over a particular period of time.

Central bank liabilities may also include certificates of deposit or short-term monetary instruments issued by the central bank and held by the commercial sector. Certificates of deposit are typically issued as a method for absorbing excess liquidity from the commercial banking sector. ${ }^{3}$

Taken together, banknotes, reserves, and certificates of deposit constitute what is known as central bank money.

\footnotetext{
${ }^{3}$ It is worth noting that sterilization of excess central bank liquidity and the associated reduction in the amount held in commercial bank reserve accounts at the central bank does not reduce a commercial bank's lending capacity to the real economy in any way. As noted by Peter Stella, former head of the Central Banking and Monetary and Foreign Exchange Operations Divisions at the International Monetary Fund, "In a modern monetary system-fiat money, floating exchange rate world-there is absolutely no correlation between bank reserves and lending. And, more fundamentally, that banks do not lend reserves" (Kaminska, 2012).
} 


\section{Assets}

The asset side of a central bank's balance sheet includes those assets - domestic and foreign - that 'back' a central bank's liabilities.

Foreign exchange assets include those assets denominated in currencies other than the national currency, as well as holdings of precious commodities such as gold. In some countries, these will include government foreign exchange holdings if held on the central bank balance sheet.

Domestic currency debt includes assets denominated in the national currency issued by both the government and the private sectors. Domestic debt can consist of holdings of government debt acquired in regular central bank short-term money market operations. More recently, and especially in countries that have introduced quantitative or credit easing operations, this category has also come to include holdings of government, financial, and non-financial debt bought outright by the central bank, sometimes on behalf of the government to increase the supply of liquidity to the economy.

The asset side of the balance sheet also includes loans by a central bank to the financial sector - typically banks - through liquidity insurance and stabilization lending operations.

\section{Equity and capital}

Unlike private financial institutions, central banks are not subject to regulatory capital requirements (Rule, 2015). Given that central banks are typically owned by the state, the decision of how much capital a central bank holds is typically a question of political economy rather than purely finance.

The question of whether the financial strength of a central bank is important for its ability to deliver its objectives has attracted widespread interest in literature. There is some consensus, as noted by former Bank of Japan Governor Fukui (2003), that central bank concerns with the soundness of their own capital base are typically focused on 'political economic instincts,' rather than just purely economic reasons. As a result, capital buffers typically vary significantly among central banks.

There is markedly less consensus, however, about the level of capital that central banks should hold.

Though in theory central banks are not constrained by liquidity and can operate even when negatively capitalized, some of the literature argues that a strong central bank balance sheet position helps underpin public confidence in the central bank's operational independence and commitment to fulfilling its mission and objectives, free from undue influence from their political masters. For example, Adler et al. (2012) use linear and nonlinear techniques on a sample of 41 countries and find that central bank financial strength can be a statistically significant factor explaining large negative interest rate deviations from "optimal levels." Stella $(2008 ; 2011)$ finds that inflation in central banks with weak financial positions is on average more than twice as high as for those central banks with stronger financial positions.

In the same vein, Perera et al. (2013) analyze a cross-section of countries and find a statistically significant and robust negative relationship between central bank financial strength and inflation. On the basis of this, they conclude that the financial health of a central bank's balance sheet is an essential pre-condition for desirable policy outcomes. Similarly, Del Negro and Sims (2015) argue for central banks with large balance sheets composed of long-term nominal assets to have access to, and be willing to ask for, support for its balance sheet from the fiscal authority. Otherwise, their ability to control inflation may be at risk. Interestingly, Benigno and Nisticò (2015) find that, in the absence of support from a central fiscal authority, large and recurrent central bank losses can undermine the central bank's long-run solvency and should be resolved through a prolonged increase in inflation.

To the contrary, Benecká et al. (2012) conclude, on the basis of a cross-country analysis, that the explanatory power of central bank financial strength indicators is rather weak. Instead, they note that the other factors (including the adoption of an inflation targeting regime) have a more significant impact on inflation.

Overall, the relationship between central bank finances and their policy outcomes is likely to be a complex one, with many factors at play. In our analysis, we do not concentrate on the direct links between central bank capital and policy outcomes, but rather share the views of Cukierman (2011) that the finances of the central bank need to be assessed in the broad context of other institutional aspects, such as the range of central bank responsibilities, risks assumed, independence, the exchange rate regime, and the degree of fiscal responsibility.

In keeping with Fry (1993), we also assume that a central banks' fiscal or quasi-fiscal activities undermine both their independence and monetary policy objectives. 


\section{THE NATIONAL BANK'S BALANCE SHEET BEFORE AND AFTER THE CRISIS}

\section{Pre-crisis: 2001-2007}

Figures 2 and 3 below show the NBU's assets and liabilities in both absolute terms and as a percentage of the NBU's balance sheet between 2001 and present day.

Taking the pre-crisis period of 2001-2007:

- The liabilities side of the balance sheet is dominated by three components: notes and coins; liabilities to the IMF stemming from previous assistance; and accounts of banks and the government at the NBU. During the period of 2001-2007, notes and coins rise both in absolute terms but also as a share of the total balance sheet (from $31 \%$ of total balance sheet size at the start of 2001 to a high of $63 \%$ at the end of 2007), reflecting the traditional importance of cash in the Ukrainian economy.

- On the assets side, by far the biggest component is holdings of foreign currency-denominated assets (including monetary gold), which rise from a low of $43 \%$ at the start of 2001 to $91 \%$ at the end of 2007), reflecting the NBU's pre-crisis fixed exchange rate targeting regime.

Figure 2. NBU liabilities and equity: absolute levels and as a percentage of total balance sheet size

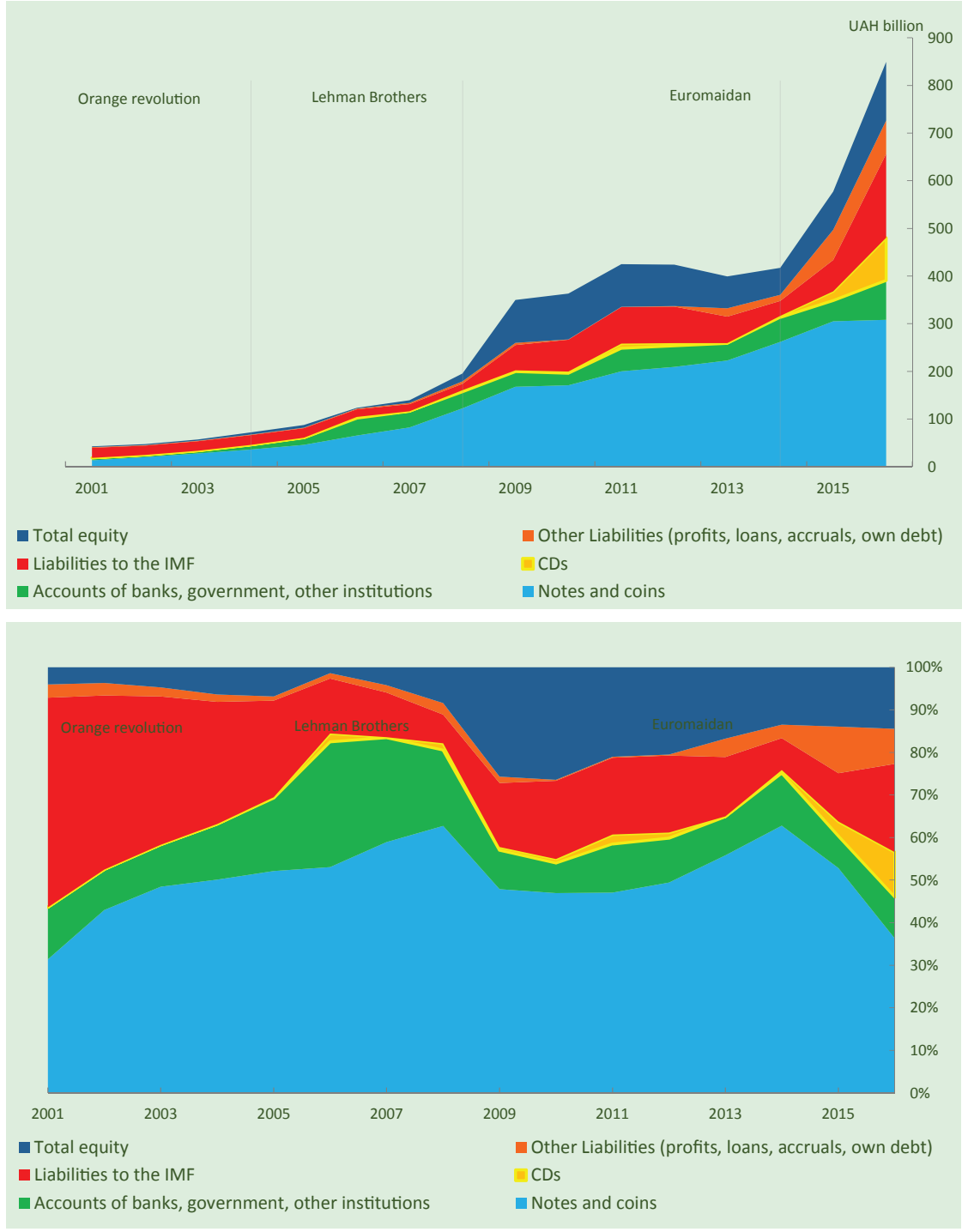


Figure 3. NBU assets: absolute levels and as a percentage of total balance sheet size
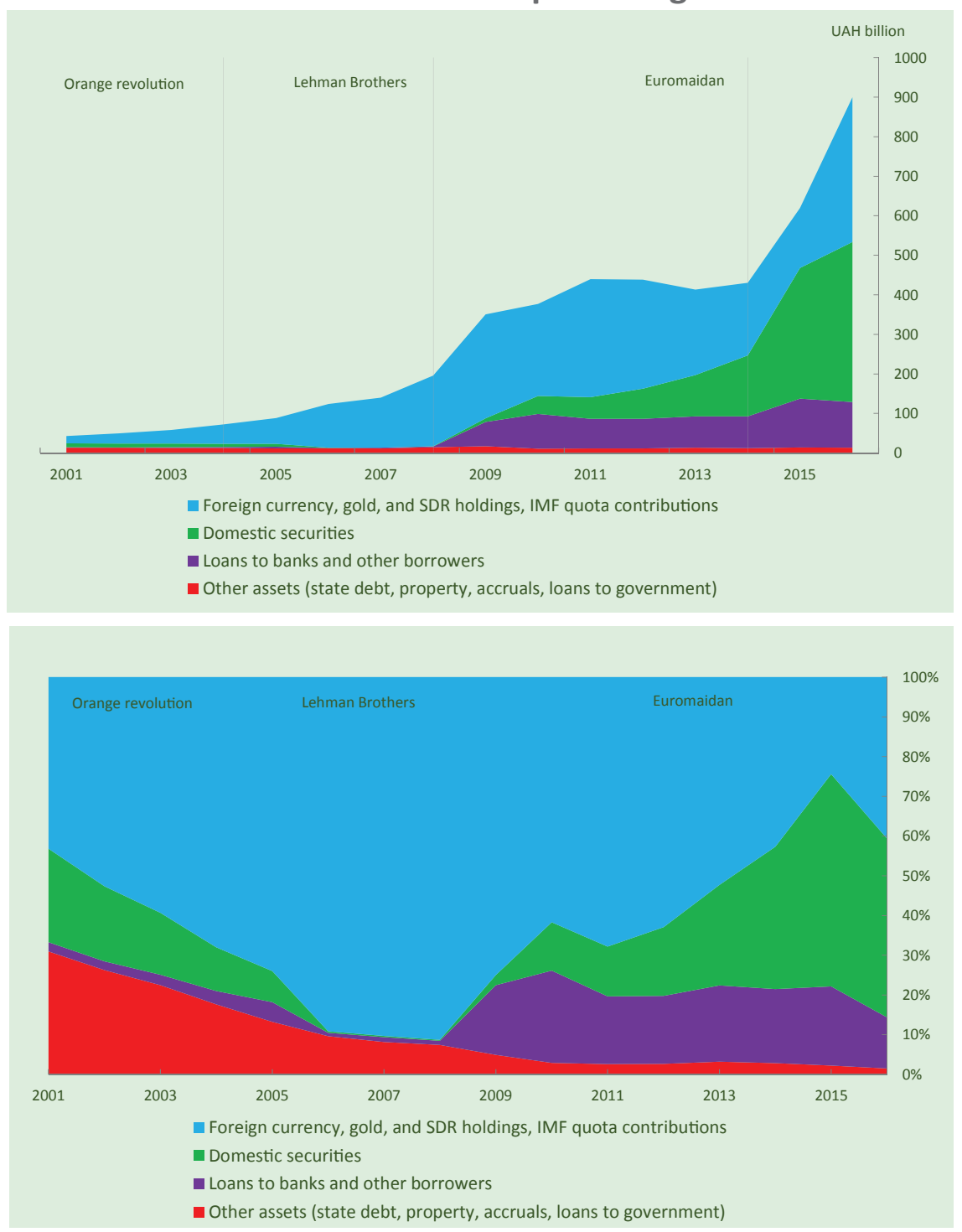

Source: NBU calculations.

\section{The global financial crisis: 2007-2009}

The global financial crisis saw a significant expansion in the NBU's balance sheet, which expanded from 27\% of GDP at the end of 2007 to $40 \%$ of GDP at the end of 2010 .

In terms of underlying components, the increase in the size of the NBU's balance sheet was driven by two factors:

- Changes in the NBU' FX reserves: Following the initial correction of the hryvnia in Autumn 2008, the NBU spent a significant amount of foreign reserves in a bid to find a new level of 'resistance' and protect the currency from further depreciation. Official reserves terms fell from a peak of USD 38 billion in August 2008 to USD 24.5 billion in April 2009. It was only after a further depreciation of the hryvnia that foreign exchange reserves in USD terms started recovering in line with an improvement in the balance of payments position. The depreciation of the hryvnia meant an increase in the NBU's equity (dark blue swathe in Figure 2) owing to realized and unrealized profit from the revaluation, in hryvnia terms, of the NBU's foreign exchange reserves (light blue swathe in Figure 3). 
- Provision of liquidity to the banking sector: In response to a bank run caused by rumors of insolvency of a particular bank, increasing strains in the global financial system, and, in particular, in bank funding markets, the NBU offered liquidity to the banking sector in a number of operations. As a result, claims on banks increased from UAH 6 billion in August 2008 to UAH 87.5 billion at the end of 2009. This provision of liquidity (purple swathe in Figure 3 ) initially led to a corresponding liability in the form of an increase in notes and coins in circulation (light blue swathe in Figure 2). However, following the rapid devaluation of the hryvnia, the NBU's liquidity support to the commercial sector was used to purchase foreign currency, which caused additional pressure for further devaluation.

\section{Accumulation of imbalances: 2010-2013}

Seen solely through the perspective of its overall size, there is little noteworthy about the NBU's balance sheet between 2010 and 2013, apart from a fall in the overall size of the NBU's balance as a percentage of GDP, from 40\% of GDP at the end of 2009 to $29 \%$ of GDP at the end of 2013 . However, a closer look at the underlying balance sheet components reveals the emergence of imbalances within the Ukrainian economy. We focus on three of the most important:

- An unsustainable exchange rate target and current account deficit: In 2010, the NBU decided to fix the exchange rate close to the level of UAH 8 to the dollar, pausing a short but significant period of volatility in the hryvnia that had supported the economy's initial adjustment in 2008-2009. The decision to adopt an exchange rate target meant committing the NBU's FX reserves to a specific exchange rate level. Those reserves fell in USD terms from USD 26.5 billion to USD 15.5 billion between 2010 and February 2014 as weak demand for Ukrainian exports and higher imports pushed the current account deficit to $9 \%$ of GDP. This shows up in Figure 3 as a relative fall in the light blue swathe.

- Imbalances in public finances: The NBU's holdings of government bonds (green swathe in Figure 3) expanded from UAH 53 billion to UAH 168 billion between the start of 2010 and February 2014. Purchases of government bonds by the NBU supported the financing of the State's budget deficit and quasi-fiscal deficits through assistance of the national oil and gas company 'Naftogaz' and the state owned banking sector. The NBU's presence in the market acted as a disincentive for the State to introduce necessary reforms to the energy and banking sectors, creating a vicious cycle of growing fiscal and quasifiscal deficits and further assistance by the NBU. ${ }^{4}$

- A financial sector dependent on NBU support: Besides supporting the State Budget and quasi-fiscal deficit, the NBU also provided further direct financial assistance to the commercial sector through refinancing loans provided during the 2008 crisis and providing new lending to banks. As the degree of support increased, the banking sector became increasingly reliant on the NBU, and by default, to its ultimate guarantor - the Ukrainian State.

By 2013, these imbalances were such that, in spite of an improvement in the headline economic numbers, the Ukrainian economy had become increasingly vulnerable to internal and external financial and economic shocks, perpetuating - rather than dealing with - the fragilities exposed during the global financial crisis of 2008. The unsustainability of these imbalances would be laid bare by the crisis of 2014-2015.

\section{4-2015: Financial crisis and normalization}

During the period of 2014 and 2015, the NBU's balance sheet expanded significantly - from $29 \%$ of Ukrainian GDP at the end of 2013 to $43 \%$ at the end of 2015 - in response to the combined effect of the balance of payments, fiscal, and banking crisis. This so-called 'perfect storm' was triggered by a collapse in confidence in the economy, political turbulence, and military aggression in the beginning of 2014, even if the seeds had been sown by policies undertaken in previous years.

The crisis prompted a significant program of reform by the authorities to rebuild economic confidence and reform the financial sector, and with it, further changes in the size and composition of the NBU balance sheet.

Among the most important influences on the NBU's balance during this period were:

- The move to a floating exchange rate regime: The unavoidable decision to let the currency float in February 2014 - while painful to the real economy - led to a narrowing in the current account deficit and an easing of pressure on the NBU's foreign currency reserves, which had fallen below a level equivalent to three months of import coverage. Reserves stabilized at a low of USD 5.6 billion in February 2015 (from USD 17.8 billion at their pre-crisis level in January 2014). At the same time, the depreciation of the hryvnia by more than 300\% (from UAH 8 per USD to more than UAH 27 per USD) led to a more than doubling of the hryvnia value of the NBU's foreign currency reserves, expanding the NBU's balance sheet, and increasing their share of the balance sheet (light blue swathe in Figure 3; Figure 4). ${ }^{5}$

\footnotetext{
${ }^{4}$ By the end of 2013 , the central government deficit had risen to $4.4 \%$ of GDP, and the deficit of State Energy company Naftogaz had risen to $2 \%$ of GDP.

${ }^{5}$ Freed from the need to maintain a fixed exchange rate, the NBU's foreign currency reserves could be used to support vital functions of the state, including securing gas imports, repayment of arrears, servicing government debt, and maintaining its foreign exchange market function.
} 


\section{Figure 4. UAH/USD exchange rate (right-hand axis) and gross international reserves} (left-hand axis)

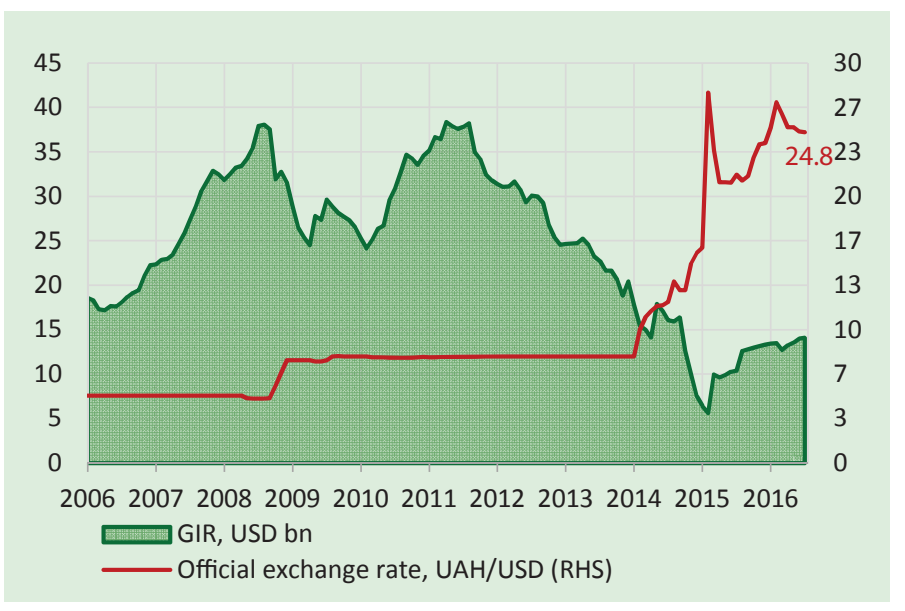

Source: NBU calculations.

- External financial support by the international community: The collapse in economic confidence and military aggression in eastern Ukraine led to a fall in exports (exports of goods and services in 2014 were down 20\% relative to 2013 levels), reducing the economy's ability to produce foreign currency inflows and replenish its foreign currency reserves. In April 2014, Ukraine signed an agreement for official financing from international creditors, supporting its foreign currency reserve position.

- Further support by the NBU to other State functions: The crisis led to further increases in the NBU's government bond portfolio as the NBU provided assistance to the State energy sector and the compensation of customers of failed banks through Ukraine's Deposit Guarantee Fund (DGF). ${ }^{6}$ Reform of the State energy sector and the reduction of Naftogaz's deficit over the course of 2015 eliminated the sector's need for additional NBU funding, but the reform of Ukraine's financial sector through 2015 made further injections of funding by the NBU into the DGF necessary to ensure the return of funds to depositors of insolvent banks.

- Demand for cash: Demand for notes and coins by the general public increased in the initial stages of the crisis in line with deposit withdrawals by the general public from Ukrainian banks. However, demand for notes and coins fell in the second half of 2014 and 2015 as a result of the combined effects of inflation, expectations of possible further devaluations, the reduction in the use of the hryvnia in the occupied territories, and initial successes by the NBU in promoting cashless payments.

- NBU support to the financial sector: Having expanded significantly in the initial stages of the crisis, the scale of NBU support to the financial sector - as measured by the amount of loans outstanding to banks - started to decline. At the same time, the commercial banking sector began to purchase increasing amounts of certificates of deposit issued by the NBU, allowing the NBU to absorb excess liquidity that had been created by its government bond purchases and the replenishment of its foreign currency reserves. The active use of certificates of deposit - which peaked in 2015 as demand for cash fell - allowed the NBU to actively manage interbank interest rates in order to fight inflation and further decrease pressure on the currency.

\section{6: Economic recovery}

The recovery in the Ukrainian economy recovery gained traction in 2016, supported by the Ukrainian authorities' ambitious program of fiscal, monetary, and financial sector reforms. Ukrainian year-on-year GDP turned positive at the end of 2015 (Figure 5), with inflation down to $7.9 \%$ in July 2016 (Figure 6). Lending to the real economy remained weak, but metrics of financial resilience improved in the first half of 2016. Reduced downward pressure on the hryvnia allowed the NBU to start repurchasing foreign currency in domestic markets, replenishing its reserves from their 2015 lows. 
Figure 5. Ukrainian Real GDP growth, \%

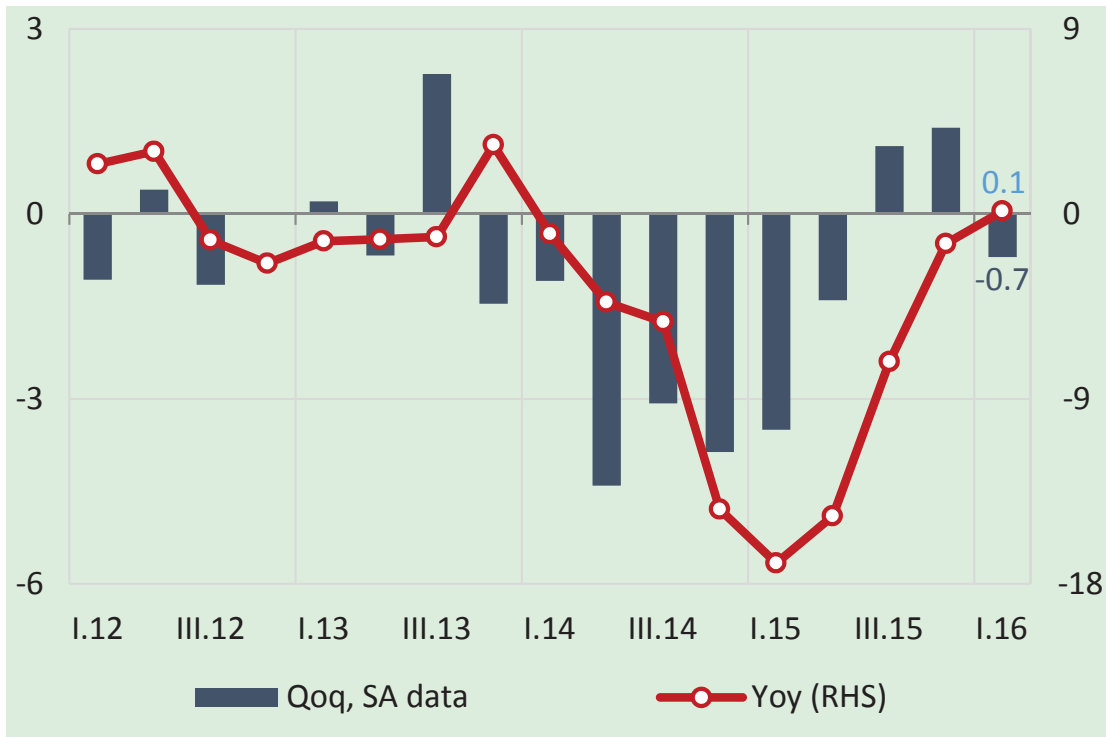

Figure 6. Ukraine inflation indicators, \%

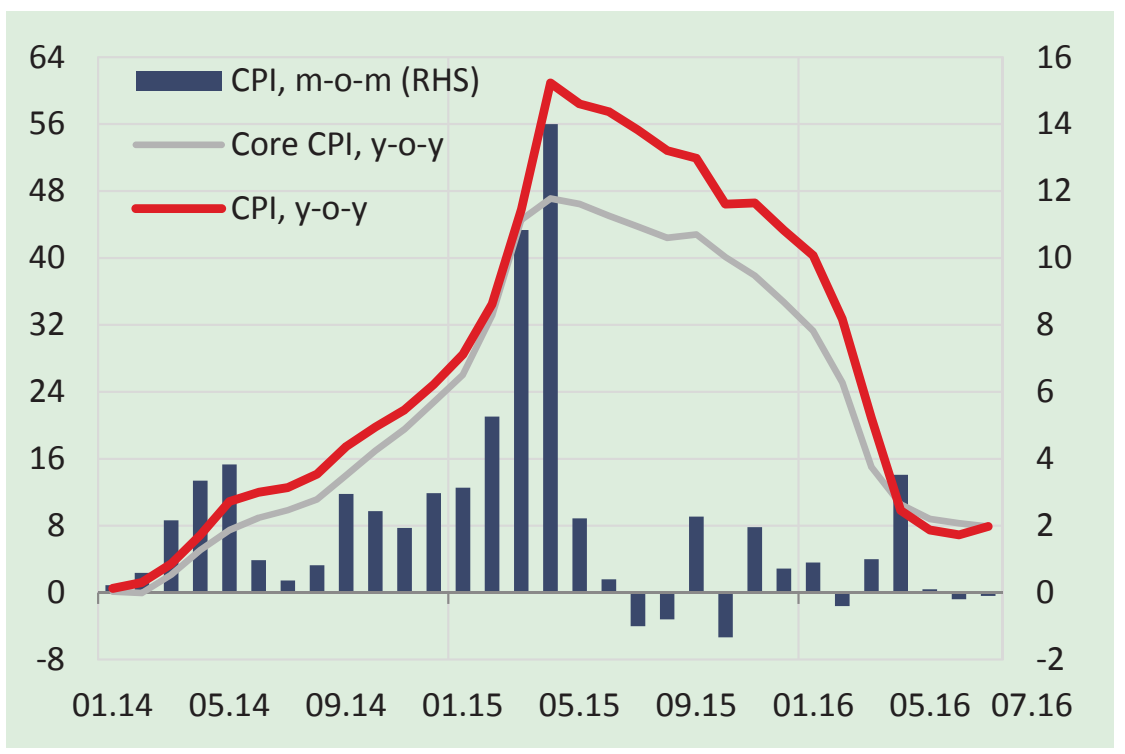

Source: State Statistics Service of Ukraine.

Reforms in the fiscal and quasi-fiscal (mainly energy) sectors and the clean-up of Ukraine's banking sector allowed the NBU to shift to a more conventional monetary policy framework based on simple, clearly defined objectives: the achievement of the NBU's inflation target and the accumulation of international reserves.

From the NBU's balance sheet point of view, the recovery of the Ukrainian economy meant that:

- The NBU's new monetary policy focused on the rebuilding of its international reserves and issuance of certificates of deposits as the primary tool for operationalizing monetary policy decisions on key policy interest rate.

- The reduction in fiscal dominance and a shift in the authorities' stance from crisis mode to a more conventional policysetting mode meant that the NBU's holdings of government bonds started to fall for the first time since 2008, in line with repayments to the NBU of bonds previously used to support the State Budget and quasi-fiscal needs (Figure 7).

- The NBU's loans outstanding to the banking sector also fell as a result of the more positive outlook for the financial system, naturally offsetting against the sterilization requirements from NBU purchases of foreign currency (Figure 8). 
Figure 7. Government Securities Held by NBU (as of 01.08.2016), UAH billion

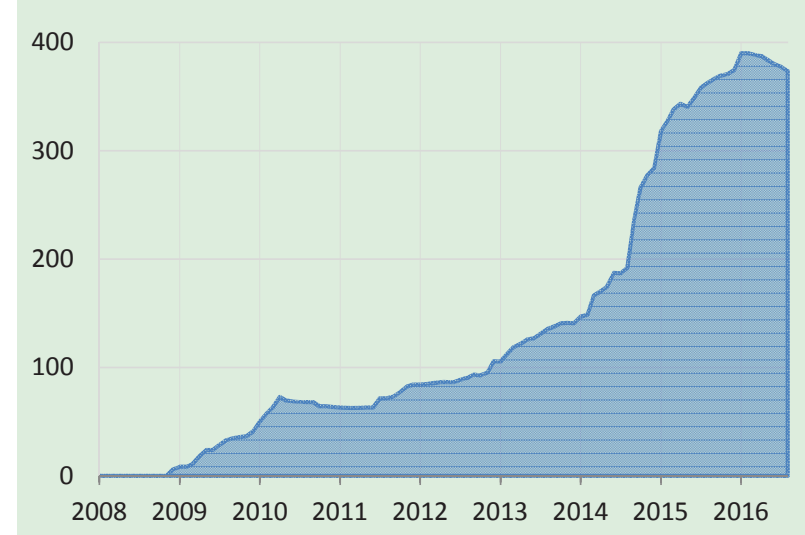

Source: NBU calculations.

Figure 8. The Stock of Refinancing Loans (as of 01.08.2016), UAH billion

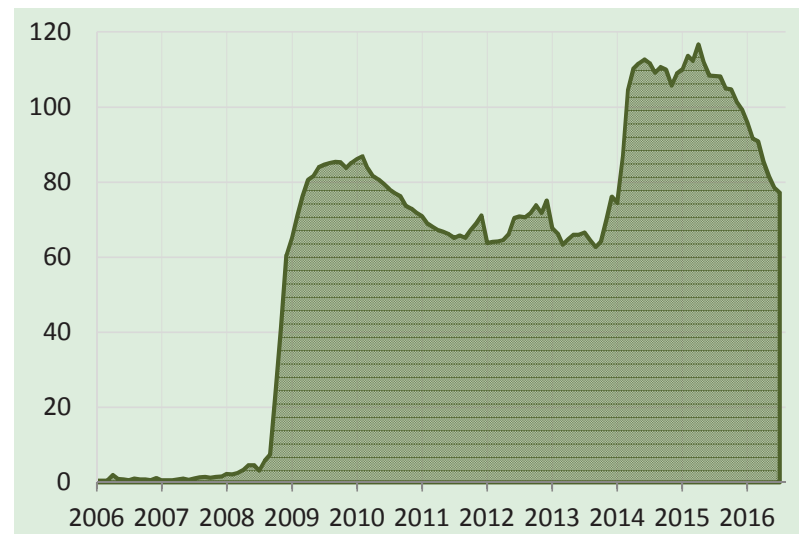

Source: NBU calculations.

The next section presents a simple simulation that maps the possible future evolution of the NBU's balance sheet over the next five years.

\section{A SIMPLE SIMULATION OF THE FUTURE EVOLUTION OF THE NBU'S BALANCE SHEET: 2016-2020}

\section{Assumptions}

Our simulation rests on the following assumptions:

- The Ukrainian economy follows a similar path to that of other economies that have transitioned from fixed exchange rate regimes to inflation targeting regimes (for example, the Czech Republic, Poland, and Israel);

- There are no economic, financial, or political shocks to the Ukrainian economy and no requirement by the State for the NBU to support its budget;

- The NBU's holdings of foreign assets increase in line with the recovery in the economy (increase in exports and foreign investment) and the NBU's objective of replenishing its international reserves;

- The NBU exercises an active interest rate policy in line with its price stability objective, with lower interest rates as the economy recovers;

- The primary instrument of monetary policy is through the issue of certificates of deposit;

- The NBU makes use of additional means of sterilization through redemption of government bonds, liquidation of collateral, and repayments of its loan portfolio;

- The amount of cash in the economy falls as a share of GDP in line with an increase in cashless transactions. 


\section{RESULTS}

Figure 9 shows the NBU's balance sheet in absolute terms and as a share of nominal GDP, with the results of our simulation for the period of 2016-2020. The absolute size of the NBU balance sheet increases, but its size as a share of GDP falls from $41 \%$ at the end of 2016 to $35 \%$ at the end of 2020 as economic growth recovers.

\section{Figure 9. NBU balance sheet in absolute terms and as a share of GDP}

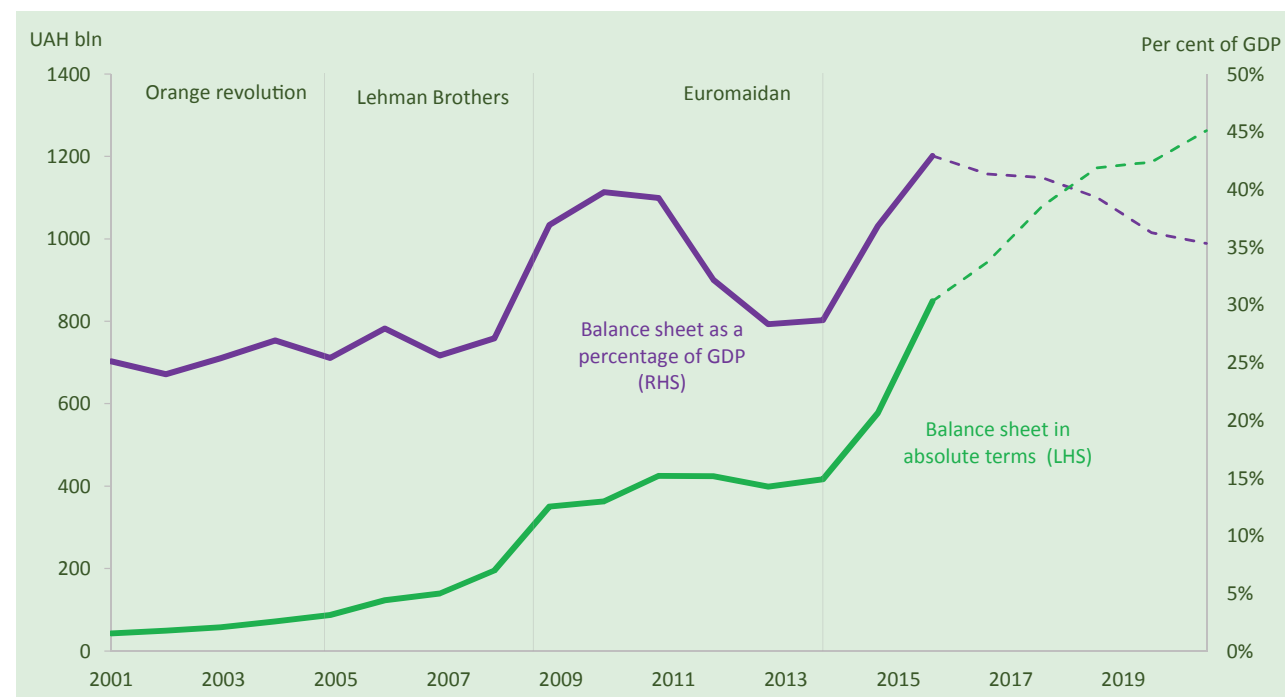

Source: NBU calculations.

Figure 10 and 11 below show the NBU's liabilities, equity, and assets while incorporating the results of our simulations covering the period of 2016-2020.

\section{Figure 10. NBU liabilities and equity: absolute levels and as a percentage of total balance sheet size}

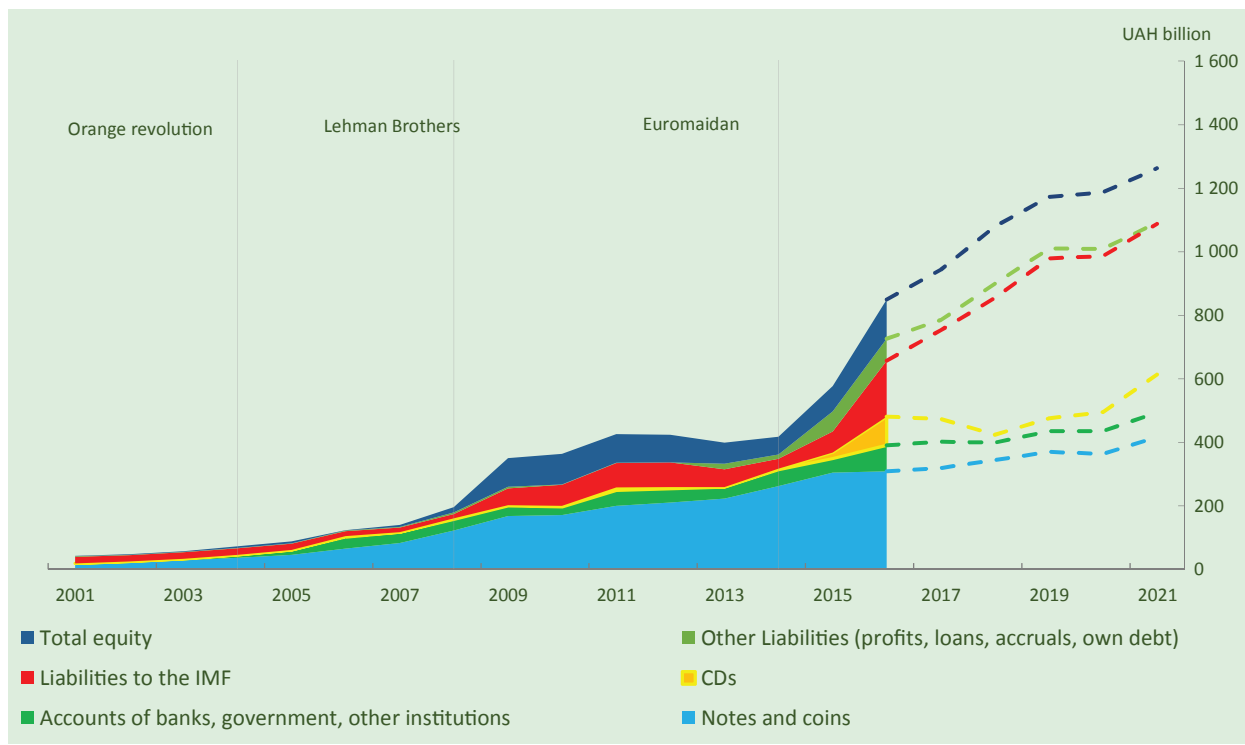




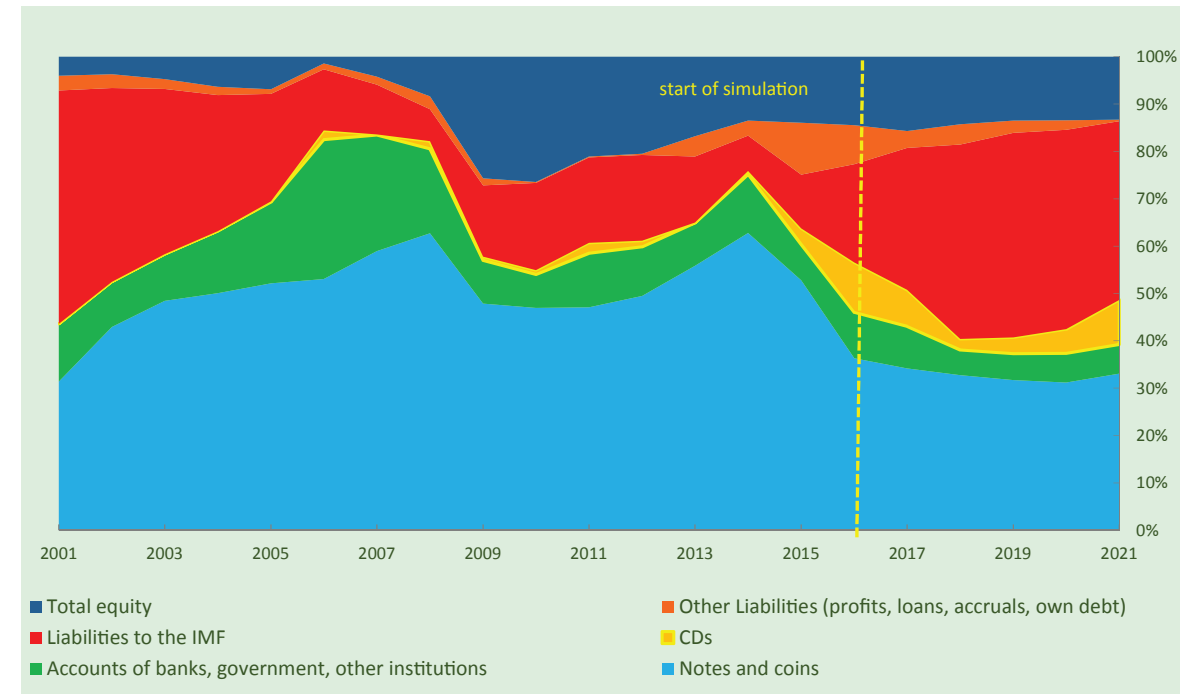

Source: NBU calculations.

\section{Figure 11. NBU assets: absolute levels and as a percentage of total balance sheet size}

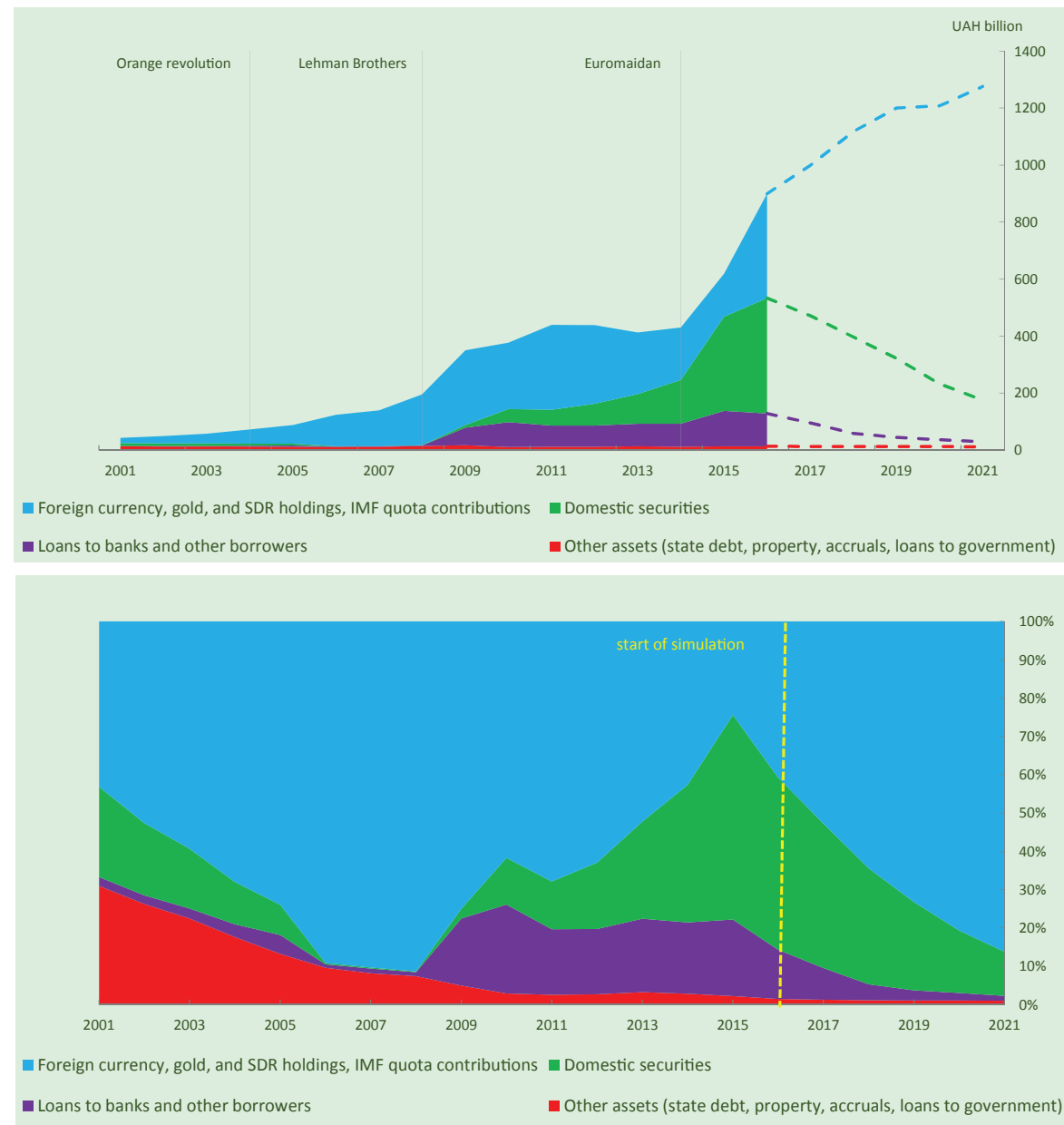


The results of our simulation are consistent with the NBU's balance sheet trending back to its pre-crisis state, albeit with some salient differences.

- On the liabilities side, our simulation shows a reduction in the share of notes and coins (light blue swathe in Figure 10) consistent with the increase in electronic (i.e., cashless) transactions in the economy. The simulation also shows an increase in the amount of certificates of deposit issued by the NBU (yellow swathe in Figure 10) to sterilize excess liquidity in the system caused by accumulation of foreign exchange inflows into Ukraine as the economy gathers pace.

- On the assets side, the exercise shows a fall in the amount of outstanding NBU loans to the commercial sector (purple swathe in Figure 11) as it repays the NBU's financial assistance, a reduction in the NBU's holdings of government bonds (green swathe in Figure 11) as these are repaid back to the NBU, and an increase in the NBU's FX holdings (blue swathe in Figure 11) consistent with the increase in FX inflows as the economy recovers.

- On the equity side, our simulations are consistent with the NBU's profits falling significantly during our five-year forecast horizon. This is the result of lower income from the impact of the stability of the hryvnia on its foreign exchange reserves, the lower stock of bonds and loans outstanding to the government and banking sector, and the increased cost of monetary policy implementation through the issue of certificates of deposit.

More specifically, the likely fall (but not the complete elimination) in profits is consistent with a reduction in distributions into the NBU's own reserve fund, and a reduction in distributions to the State Budget. We discuss the policy implications of this for the NBU's independence in the next section.

\section{POLICY CONCLUSIONS AND RECOMMENDATIONS}

Our simulation exercise shows the NBU's capital stabilizing at a level of 13-16\% of the NBU's balance sheet between 2016 and 2020. However, seen as a ratio to the NBU's domestic liabilities, the NBU's capital falls from $29 \%$ of domestic liabilities at the end of 2016 to $27 \%$ at the end of $2020 .^{7}$

While there is no standard definition of what constitutes an adequate amount of central bank capital, we assume that, past a certain point, a fall in the capital of a central bank can be detrimental to its ability to fulfill its objectives in an independent way (Bindseil, 2004). Falling profits erode the financial strength of a central bank and its perceived and actual ability to fulfill its functions without requiring fiscal transfers from the State.

The amount of capital needed to ensure continued independent operational and policy capability is a function of a number of issues, including accounting mechanisms, and profit distribution and risk-sharing arrangements (Archer, 2013). The table below notes six considerations for ensuring independent financial strength, as noted in Archer (2016). For each condition, we note the current status vis-à-vis the NBU. ${ }^{8}$

\section{Table 2. Considerations for ensuring financial strength vis-à-vis the current status of the NBU}

\section{David Archer's principles}

1 A good amount of starting capital.

2

A dividend distribution policy that has as its first priority rebuilding the starting level of capital should equity fall below that.

Some form of recapitalization commitment in law for situations where losses have been made in pursuit of objectives clearly inside the mandate.

4 Supplemental to that, arrangements that transfer financial risks to the treasury when non-standard policy actions are being undertaken.

Where a decision has been taken to mark-to-market the central bank's assets and liabilities, unrealized revaluation gains and losses should be excluded from the amount available for distribution as dividends.

Finally, as a safety net protection for the central bank's financial strength, a limit on the size of any one year's distribution to the government, aimed at preventing income volatility from distributions in and out of the central bank's coffers.

\section{National Bank position}

The NBU's authorized capital is UAH 100 million (this can be increased by the NBU Council).

The NBU is obliged to retain as reserves profits amounting to $10 \%$ of the NBU's domestic liabilities.

The NBU is allowed to cover any losses from its reserves. The State is obliged by law to cover any losses exceeding the NBU's reserves.

The NBU does not have an indemnity system that passes on the risk of exceptional losses to the State.

The NBU does not book unrealized revaluations of gains and losses to profits.

The NBU's distributions to the State in any one year must not exceed the profit for that year.

\footnotetext{
${ }^{7}$ Domestic liabilities are defined here as notes and coins plus accounts of government and banks, liabilities on profit distribution to the State Budget, and certificates of deposit issued by the NBU.

${ }^{8}$ These six conditions were set out by David Archer in his intervention at the National Bank of Ukraine's annual conference on Transforming Central Banking held in Kyiv on 19-20 May 2016
} 
Taking the table above into account, two key recommendations stand out:

1. It is clear that, in the NBU's case, it is the NBU's reserves and not the authorized capital that matters from the point of view of financial strength. While there is a maximum amount of profits that can be distributed to the general reserve in any given year (equivalent to $10 \%$ of the NBU's monetary liabilities), there is no minimum requirement for the reserve to be replenished by the State should it be depleted in a crisis - only an assumption that the NBU would replenish it from profits in subsequent years. If the NBU reserve is to truly serve as a buffer against financial crisis, it would be preferable to have a minimum required general reserve together with a recapitalization agreement for the State to replenish the reserve should it fall below its minimum level.

2. Separately, it makes sense for the NBU to think about how to put in place arrangements that would ensure that any losses - and also profits - from non-standard central bank operations can be transferred directly to the State Budget. This is especially important given the increasing share of the NBU's balance sheet represented by the government's foreign currency reserves. These arrangements could take the form of a ring-fencing of specific portions of the NBU's balance sheet, or an indemnity by the State to the NBU covering specific operations.

\section{CONCLUSION}

The balance sheet of the NBU is core to its mission of promoting price and financial stability and economic growth. Besides being an integral part of the NBU's toolkit, the NBU's balance sheet also serves as a window into the forces that shape the economy.

The 2014 crisis represented a significant expansion in the NBU's balance sheet. As the authorities' ambitious program of reforms bears fruit and the economy recovers, the NBU's balance sheet should fall as a share of GDP.

It is essential for the NBU to continue to reinforce its operational independence to ensure it can fulfill its objectives in a transparent and accountable manner. Crucial to this is the assignment of clear goals and operational independence by the relevant authorities. However, equally as important is the need for adequate capital and the right risk-sharing, profit distribution, and recapitalization arrangements, particularly as the economy stabilizes and the NBU's profits fall in the coming years. Reinforcing these arrangements will ensure that the NBU can continue focusing on its mission of fulfilling its objectives without recourse to the government during times of crisis.

\section{References}

- Adler G., Castro P., Tovar C.E. (2012). Does Central Bank Capital Matter for Monetary Policy? Working Paper, No. 12-60, IMF. Available at: http://www19.iadb.org/intal/intalcdi/PE/2012/09764.pdf

- Archer D., Moser-Boehm P. (2013). Central Bank Finances, Papers, No. 71, BIS. Available at: www.bis.org/publ/bppdf/ bispap71.pdf

- Benecká S., Holub T., Kadlčáková N., Kubicová I. (2012). Does Central Bank Financial Strength Matter for Inflation? An Empirical Analysis. Working Paper, No. 3, Czech National Bank.

- Benigno P. and Nisticò S. (2015). Non-Neutraility of Open Market Operations, Centre for Economic Policy Research. Discussion Paper, No. 10594.

- Bindseil U., Manzanares A., Weller B. (2004). The Role of Central Bank Capital Revisited. Working Paper Series, No. 392, ECB. Available at: https://www.ecb.europa.eu/pub/pdf/scpwps/ecbwp392.pdf?e7bba27cdd7b6 53529fc35400ff0a3c0

- Caruana J. (2012). Why central bank balance sheets matter, Are Central Bank Balance Sheets in Asia too large? Bank for International Settlements papers, No. 66. Available at: https://www.bis.org/publ/bppdf/bispap66.htm

- Cross M., Fisher P., Weeken O. (2010). The Bank's balance sheet during the crisis. Bank of England Quarterly Bulletin, Vol. 50, No. 1, pp. 34-42.

- Cukierman A. (2011). Central Bank Finances and Independence - How Much Capital Should a CB Have? In The Capital Needs of Central Banks, S.Milton and P.Sinclair (eds), Routledge, London and New York.

- Del Negro M., Sims C. A. (2015). When does a Central Bank's Balance Sheet Require Fiscal Support? Federal Reserve Bank of New York. Staff Reports, No. 701. 
- European Central Bank (2013). Central Bank Balance Sheet Expansion and Financial Strength in crisis times: the case of the Eurosystem. ECB Monthly Bulletin, Box 5, September 2013, pp. 41-44. Available at: https://www.ecb.europa.eu/pub/ pdf/other/mb201309_focus05.en.pdf

- Fry M. (1993). The Fiscal Abuse of Central Banks. Working Paper, No. 93-58, IMF. https://doi.org/10.5089/9781451966565.001

- Fukui T. (2003). Challenges for Monetary Policy in Japan. Speech to the Spring meeting of the Japan Society of Monetary Economics, 1 June (extracts reprinted in Pringle, R. (2003): Why Central Banks Need Capital, Central Banking, Vol. 14, No. 1.

- Kaminska I. (2012). The Base Money Confusion. The Financial Times Website, 3 July 2012. Available at: http://ftalphaville.ft.com/2012/07/03/1067591/the-base-money-confusion/

- Pattipeilohy C. (2016). A Competitive analysis of developments in central bank balance sheet composition. Working Paper, No. 510, De Nederlandsche Bank.

- Perera A., Ralston D., Wickramanayake J. (2013). Central Bank Financial Strength and Inflation: Is There a Robust Link? Journal of Financial Stability, Vol. 9, No. 3, pp. 399-414.

- Rule G. (2015). Handbook - No. 32, Understanding the central bank balance sheet, Centre for Central Banking Studies, Bank of England. Available at: http://www.bankofengland.co.uk/education/Documents/ccbs/handbooks/pdf/ ccbshb32.pdf

- Stella P. (2011). Central Bank Financial Strength and Macroeconomic Policy Performance. In The Capital Needs of Central Banks, S. Milton and P. Sinclair (eds), Routledge, London and New York.

- Stella P., Lonnberg A. (2008). Issues in Central Bank Finance and Independence. Working Paper, No. 08-37, IMF. Available at: http ://www.imf.org/external/pubs/ft/wp/2008/wp0837.pdf 